\title{
The Empirical Research of the Effect of Financing Constraints on Investment Efficiency
}

\author{
Based on Chinese Listed Companies
}

\author{
Shuanghai Li \\ Business School \\ Sichuan University \\ Chengdu, China
}

\author{
Xinwen $\mathrm{Hu}$ \\ Business School \\ Sichuan University \\ Chengdu, China
}

\begin{abstract}
Based on the data of the Chinese Listed Companies in 2012-2016 years as the research sample, this paper carries out an empirical research on the relationship between the financing constraints and investment efficiency of Chinese listed companies from the perspective of different regions, industries and property rights. The result shows the fact that the lower the financing constraints are the higher the efficiency of investment is, and to enhance the enterprise value, the investment efficiency of nonstate-owned enterprises is easily to be improved than that of the state-owned enterprises through easing financing constraints; similarly, the enterprises in the Midwest of China is more easily than eastern enterprises, the information technology service industry is more easily than other.
\end{abstract}

Keywords-financing constraints; investment efficiency

\section{INTRODUCTION}

If the capital market was perfect, as the theory of MM (1958), there should be no cost difference between the external and internal capital, and both of them can achieve a perfect alternative. But in the actual situation, the imperfect capital market often makes the cost of obtaining external capital higher than the internal capital for enterprises, that is, the enterprise faces financing constraints. At present, there are many problems in China's enterprises, such as irrational financing structure, funds gaps for business operation activities which are hard to be financed on time and large financing constraints. The financing activities and investment activities of enterprises are both independent and interrelated. While financing activities can solve the source of corporate funding, investment activities solve the problem of capital utilization. Because of the cost of capital, there are cost differences between different financing choices, which lead to the different financing structures; on the constraints of enterprise capital financing, how to raise funds to achieve efficient allocation and maximize the efficiency of investment are the problems which the investment needs to solve.

The financing situation of enterprises would have a more direct impact on investment decisions, in case of serious financing constraints of enterprises, those positive NPV investment projects may be given up because of the shortage of funds, which may result in a shortage of investment; if the lower financing constraints of enterprises are facing, the adequate internal funds may lead to excessive investment in investment projects, the investment deficiency and excessive investment will reduce the enterprise investment efficiency, and are not conducive to the improvement of the enterprise value.

In order to deep study the financing constraints enforced by the enterprises from many perspectives, the paper adopts a empirical method with large sample to explore the impact of the financing constraints to investment efficiency with the latest data of listed companies in Chinese capital market of in recent years, aiming to come in line with the Chinese market status of the conclusion, and put forward suggestions to solve this a problem.

\section{LITERATURE REVIEW}

According to Modigliani and Miller (1958), the financing decisions and investment decisions of enterprises are separated from each other in the complete capital market and do not affect each other, that is, the value of enterprises depends only on investment behavior but not on corporate financing behavior. However, there are various frictions in the financial market, such as information asymmetry, incomplete contract and agency problem, which will result in the fact that the financing situation of enterprises directly affects the investment behavior and investment efficiency.

After reading a lot of domestic and foreign literature, we found that in most scholars' researches of the relationship between financing constraints and investment, internal cash flow was generally used as the intermediate variable, to study the two through the indirect research on the sensitivity between financing constraints and investment-cash flow. In these literature, different conclusions were drawn due to different measures of financing constraints, different indicators choices, and different samples, the development trend of the study on the relationship between financing constraints and investment has experienced three stages of positive correlation, negative correlation and non-linear correlation.

\section{A. Positive Correlation}

Basing on information asymmetry and pecking order theory, Fazzari (1988) (hereinafter referred to as FHP) proved 
the positive correlation between investment cash flow sensitivity and financing constraints with the American manufacturing enterprise data, creating pioneer of research on the investment efficiency of enterprises base on the investment - cash flow research. On basis of which, a large number of empirical researches also have justified the conclusion of FHP from other perspectives thereafter, such as the scale of the enterprise, the rate of dividend payment, and the relationship of the group.

Basing on the sample of data of 3547 U. S. manufacturing firms in the year 1971-2000, Almeida and Campello (2004) had carried out his research on financing constraints with measurement on the scale of the firms, the dividend payment rate, bond rating, commercial paper level and other factors. The result showed that the corporate financing constraints are positively correlated with the investment-cash flow sensitivity; On the reference of the FHP (1998) method, Feng Wei (1999) study on the influence of the financing constraints on the investment cash flow, adopting the dividend payment rate as the substitute variables of financing constraints, and using financial data of 135 Manufacturing Listed firms in China from 1995 to 1997 as the sample. The results support the view of FHP that the two have a positive correlation. In addition, Gangopacihyay, Lensink and Molen (2004); Degryse and Jong (2006) justified FHP's view with different financing constraint measurement methods.

\section{B. Negative Correlation}

Kaplan and Zingales (1997) (hereinafter referred to as KZ) and dealt with the sample data of FHP (1998), with the research sample of FHP to measure the financing constraints based on the comprehensive financial status of cash flow, growth rate, dividends, interest cover ratio, debt and so on, The results showed that the sensitivity of investment to cash flow in the research sample of enterprises performs differently under different degree of financing constraints, the sensitivity of The sensitivity of enterprises with lower corporate financing constraints is higher than the sensitivity of enterprises with financing constraints of enterprises with is high, that is to say, the financing constraints are negative correlated with the investment cash flow sensitivity. This verification result is on the contrary with the results of FHP. As Vogt (1994) pointed out, if enterprises were subject to financing constraints, they will undercapitalize, and the sensitivity of investment cash flow is positive. If enterprises over-invested due to the agency problem, the investment cash flow sensitivity is negative. Lian Yujun and Cheng Jian (2007) thought that the impact of financing constraints on the investment cash flow sensitivity is related to the amount of financing that are obtained by enterprises, while the impact of agency problems on the investment cash flow sensitivity is related to the business efficiency.

Cleary (1999) improves the research method of KZ (1997). On the one hand, the financial constraints are measured by the comprehensive financial situation was adopt on the measure of financing constraints. On the other hand, the sample size of $\mathrm{KZ}$ was expanded, and the data of 1317 firms in the United States from 1987 to 1997 were studied. The results showed that the relationship between financing constraints and investment cash flow sensitivity is inverse, and this conclusion supported the view of $\mathrm{KZ}$.

Taking the data of China's A share listed companies from 1998 to 2003 as samples, Li Yanxi and Du Rui et al. (2007) studied the relationship between the two on the basis of not considering the deviation of Tobin's Q calculation, Their results showed that the lower financing constraints firms showed stronger investment cash flow sensitivity than the more serious financing constraints firms, the two showed negative correlation; in addition, Palani (1998); Agung (2000; Konings) and Rizov (2003); Boyle, Guthrier; Almeida, Mozumdar (2003) (2004) are justified KZ's conclusion from different perspectives.

\section{Nonlinear Correlation}

Audertsch, Elston (2002) utilized the scale of the company as the financial constraint classification standard, and research the relationship between financing constraints and investment with the financial data of 719 firms in Germany for 1970-1986 years as the research object, The result showed that the financing constraints and investment cash flow sensitivity relationship in German sample enterprises is not simple positive or negative correlation, but showed a nonlinear relationship; Zhangkai Huang (2002) observed the relationship between the two by taking the financial data of 1235 companies from 1988 to 1998 as the research object. The result also shows that the relationship between the financial constraints and the cash flow sensitivity of the investment in the American sample enterprises is nonlinear.

Wang Jiang, Lin Chen and others (2008) take 1998-2005 years data of Shanghai and Shenzhen stock A share listed companies as the research object, and analyzed the relationship between financing constraints and investment cash flow sensitivity in perspective of corporate governance. The results are divided into two cases: when corporate governance is in good condition, there is a positive correlation between financing constraints and investment cash flow sensitivity, and when the corporate governance is poor, the financing constraints and investment cash flow sensitivity are $U$ related.

\section{HYPOTHESIS PROPOSED}

Financing is the channel for enterprises to obtain funds. Compared with those with less financing constraints, firms with financing difficulties face would be in under-investment and lower investment efficiency when facing the same investment opportunities.

Hence hypothesis $\mathrm{H} 1$ can be inferred: the financing constraints of the enterprise will affect the efficiency of investment, and the greater the financing constraints, the lower the efficiency of investment.

Lu Xiaodong (2008) found that the asymmetric financing ability between state-owned enterprises and non-state-owned enterprises is the concentrated expression of the financial mismatch at the present stage. Non-state-owned enterprises are at a disadvantage in resource acquisition or policy support when competing with state-owned enterprises, which makes their financing constraints more serious. 
Therefore, hypothesis $\mathrm{H} 2$ can be inferred that compared with the state-owned enterprises, the investment efficiency of non-state-owned enterprises is more affected by the financing constraints.

The eastern region of China takes the lead in economic development, with a high marketization degree and obvious advantages in foreign trade. While in the central and western regions located in the inland, the transportation and other facilities are still in the continuous construction, and the traditional agricultural industry still occupies a certain proportion. In comparison, central and western enterprises can be seen facing higher financing constraints.

Therefore, $\mathrm{H} 3$ can be inferred that compared to the eastern enterprises, the investment efficiency of the central and western enterprises is more significantly affected by the financing constraints.

The Hi-tech enterprises in China are in the stage of rapid development, and facing a lot of investment opportunities and investment decisions, they will have insufficient investment or excessive investment therefore the investment efficiency of enterprises reduced. Many enterprises are restricted by credit policy and financial market during the financing process. What is the impact of financing constraints on investment efficiency for Hi-tech enterprises compared with other industries?

$\mathrm{H} 4$ can be inferred that compared to other industries, the investment efficiency of high-tech enterprises is more significantly affected by financing constraints.

\section{RESEARCH AND DESIGN.}

\section{A. Data Source}

This paper selects Shanghai and Shenzhen A share listed companies from 2012 to 2016 as the research samples. After screening, 5737 data from 1309 companies was gotten. The sample selection process is following: (1) excluding the listed companies in the financial industry; (2) excluding ST companies; (3) excluding the observed values with data missing. The Sample Firms data was derived from the CSMAR, Choice database. The statistics and analysis of the data are done with the help of Excel and Stata14.

\section{B. The Measurement of Financing Constraints}

This article adopted the comprehensive financial index model proposed by Chinese scholars Li Yan and Zhang Ning (2008) as the financing constraint measurement method. When the comprehensive score FC is less than 0.54 , there is a financing constraint. In 0.54-0.95, there may be financial constraints; there is no financing constraint when the FC more than 0.95 . That is, the higher the FC value of the calculation results was, the lower the financing constraints facing enterprises. In this paper, to make the analysis convenient, opposite numbers were taken as the results of financing constraints measurement.

\section{The Measurement of Investment Efficiency}

The measurement method of investment efficiency adopted in this paper was the Tobin $Q$ value, that is, the ratio of the market value of stock to the asset of the enterprise, which can be directly found by the database.

\section{RESEARCH RESULTS AND CONCLUSIONS}

\section{A. Model}

If the hypothesis $\mathrm{H} 1$ was valid, $\mathrm{FC}$ is negative and negatively correlated with I.

\section{B. Variable Interpretation}

Among the variables used in this paper, the investment efficiency is the explained variable and the financing constraint is the independent variable. The scale of enterprise, the assets-liability ratio, the internal cash flow and the growth rate of main business are taken as the control variables, and industries and years are regarded as dummy variables.

\section{Descriptive Statistics}

According to the descriptive statistics, the mean of financing constraints is 0.111 , which indicates that there are generally financing constraints in China's listed companies, with a standard deviation of 8.577 and a high degree of dispersion. The average level of investment efficiency is 2.221, indicating that the insufficient investment is more common and the degree of dispersion is low.

\section{Correlation Coefficient}

The result of Spearman and Pearson correlation coefficient shows that there is a significant correlation between variables besides the main business growth rate which is weakly related to other variables. The financing constraints and investment efficiency are significantly negatively correlated on the level of $0.1 \%$, and the enterprise asset-liability ratio and investment efficiency have a significant positive correlation with the investment efficiency at the $0.1 \%$ level.

\section{E. Empirical Results}

The empirical results show that financial constraints are negatively correlated to the efficiency of investment at the 5\% level, which indicates that reducing financing constraints can improve the investment efficiency of enterprises, among the control variables, and the significance level of main business the growth rate is less than 5\%; the higher the asset-liability ratio, the higher the efficiency of investment; The higher internal cash flow is, the lower the investment efficiency; the larger the enterprise is, the lower the efficiency of investment.

According to the regression analysis on different natures of property right, areas, industry data, the result show that the non-state-owned enterprises are more easily than state-owned enterprises, the enterprises in the central and western of China are more easily than eastern enterprises, information technology service industry is more easily than other industries to improve investment efficiency and promote the enterprise value via the mitigating the financing constraints. 


\section{CONCLUSION AND SUGGESTION}

From the above research, we can conclude that the mitigation of corporate financing constraints can effectively improve its investment efficiency. Therefore, Chinese enterprises can explore ways to ease financing constraints and improve investment efficiency. Meanwhile, the non-stateowned enterprises, Central and western enterprises and hightech enterprises can also actively seek ways to ease financing constraints, such as fulfilling their social responsibilities and improving the quality of information disclosure. As a result, the following suggestions are put forward at the level of policy and enterprise itself.

\section{A. Policy Environment Level}

The government still needs to strengthen support for small and medium-sized enterprises and provides more financial and tax support, such as loan subsidies, loan guarantees, tax reduction and tax-free and other tax incentives. At the same time, the government also needs to guide the flow of funds from financial institutions such as state-owned banks to provide more financial support for listed companies. At the same time, needs to construct a complete system of commercial banks, and introduce foreign commercial banks to increase competition in the financial markets to promote China's large state-owned commercial banks paying more attention to the SME financing market development and improving the enterprise financing loan supply, to reduce the negative effect of increasing debt financing in the financing constraints and uncertainty.

\section{B. Enterprise's Own Level}

Because cash flow can effectively ease financing constraints and reduce financing uncertainty, in the short term, in order to improve investment efficiency, listed companies should strive to improve their profitability and reduce external financing dependence. In the long term, because equity financing can effectively ease the financing constraints faced by the listed companies, and give full play to the financing function, debt financing will aggravate the dilemma of the companies, therefore should establish a multi-level capital market base on appropriately lowering the financing threshold of listed companies, and reduce the bank loan information asymmetry, change the bank business model and risk control method of one-sided emphasizing on the hypothecary value financing, thereby the negative effect of debt financing on financing dilemma of the company can be reduced.

\section{REFERENCES}

[1] Modigliani F, Miller M H.The cost of capital, corporation finance and the theory of investment $[\mathrm{J}]$.The American economic review, 1958, 43 (3) :261-297.

[2] Fazzari S M, Hubbard R G, Petersen B C, et al.Financing constraints and corporate investment [J] .Brookings papers on economic activity, 1988,1 (1) : :141-206.

[3] Almeida HM, Campeiloand M.Weisbach. The Cash Flow Sensitivity of Cash[J]. Journal of Finance, 2004(4): 1977-1804.

[4] Hoshi T.,Kashyap A.,and Scharfstein D.Corporate Structure, Liquidity and Investment : Evidence from Japanese Industrial Groups[J].Quarterly Journal of Economics, 1991.(20):33—60.
[5] Audretsch DB, Elston JA. Does Firm Size Matter? Evidence on the impact of Liquidity Constraints on Firm Investment Behavior in Germany[J]. International Journal of Industrial Organization, 2002(20): $1-17$.

[6] Zhangkai H. Financial constraints and investment cash flow sensitivity [J]. Mimeo, University of Oxford, 2002(12): 213-240.

[7] Kaplan S N, Zingales L.Do investment-cash flow sensitivities provide useful measures of financing constraints? [J].The Quarterly Journal of Economics, 1997, 112 (1) :169-215.

[8] Vogt S C.The cash flow/investment relationship: evidence from US manufacturing firms [J].Financial management, 1994, 23 (2) :3-20.

[9] Feng Wei. Internal cash flow and enterprise investment [J]. Economic science, 1999 (1):45 - 49.

[10] Wang Jiang, Lin Chen, Wu Shinong. Financing constraints, corporate governance and investment-cash flow sensitivity - Empirical research base on Chinese Listed Companies $[\mathrm{J}]$. Contemporary Finance \& Economics, 2008 (12): 104 - 109.

[11] Yuan Weiqiu. Investment efficiency, cash holdings and enterprise value research - based on the perspective of financing constraints[J]. Economics and management, 2014, (2): 103-111.

[12] Lian Yujun, Su Zhi. Financial Constraints, Uncertainty and Firms' Investment Efficiency [J]. management review, 2009,21 (1): 19-26.

[13] Liu Fei, Zheng Xiao-ya. Measure investment Efficiency of China's Listed SMEs under Financing Constraints, $[\mathrm{J}]$. business economy and management, 2014,272 (6): 76-85.

[14] Xu Chenyang, Chen Haoliang. The Impact of financing constraints on investment efficiency under the financial mismatch: literature review [J]. Chinese management Informatization, 2015,18 (11): 139-141.

[15] Cai Jifu. Financing constraints or agency conflicts? - Research on the motivation of inefficiency investment of listed companies $[\mathrm{J}]$. financial theory, 2012, (3): 86-91. 